\title{
Optimizing Recipes of Mung Bean Pancake for Teenagers
}

\author{
Jin-Wha Lee, Eun-Soo Shin, and Hong-Soo Ryu ${ }^{\dagger}$ \\ Department of Food Science \& Nutrition, Pukyong National University, Busan 608-737, Korea
}

\begin{abstract}
To standardize the recipes for healthy fast food market potentiality, a sensory acceptability analysis, instrumental texture analysis and nutritional evaluation were performed on Korean style mung bean pancake (MPC) and modified MPC containing squid meat and soybean. Optimal ingredient formulation was revealed to be $34 \%$ mung bean, $49 \%$ pork and $17 \%$ vegetables for traditional MPC, and $21 \%$ pork, $66 \%$ squid meat and $13 \%$ soybean for modified MPC, using response surface methodology. Flavor and hardness correlated highly with overall acceptability, rather than appearance and color of traditional MPC. Higher squid levels raised adhesiveness, springiness and resilience of modified MPC, but the higher soybean levels decreased these textural attributes. Protein, lipid and total calories of modified MPC were lower than those of traditional MPC. Degree of gelatinization of modified MPC was superior to traditional MPC.
\end{abstract}

Key words: mung bean pancake, response surface methodology, sensory acceptability, optimized ingredients ratio

\section{INTRODUCTION}

Mung bean pancake is a traditional Korean food known to have high nutritional quality (1) and sensory acceptability by global consumers (2-4). The recipe for mung bean pancake, as well as other traditional Korean foods, varies in terms of the kinds, amounts and ratio of ingredients, as well as cooking techniques. These various recipes should be standardized for consumer acceptability to raise the international food market potentiality $(5,6)$.

Mung bean pancake is a typical Korean food that has a high potential for success in the fast food industry; therefore information on consumer acceptability of mung bean pancake is needed and a prototype product focused on a target population should be developed (7). The target population of consumer acceptability in this study was teenagers, because they are potent consumers of fast food and are in a critical stage for determining dietary habits, food familiarity and exposure effects (8).

Product optimization studies involve multiple formulations (9), and various approaches may be used to identify the range of optimal formulations that are critical for acceptance. Response surface methodology is one approach that is capable of estimating sensory evaluation scores for mung bean pancake from the mixture ratio of the ingredients.

The objective of this study was to develop the modeling equation for optimizing mixture ratio of mung bean pancake focused on target consumer group by response surface methodology using simplex mixture design. For the first stage, the mixture ratio of basic ingredients of traditional mung bean pancake was consumer-oriented optimized. For the second stage, pork, one of the traditional ingredients, was partially replaced with squid and soybean in order to improve the composition of fatty acids and reduce calories. The ratio of modified ingredients was also optimized. These optimum mixture ratios from consumer acceptability test could be used as reliable basic data for standardizing recipes of MPC in Korean traditional fast food market.

\section{MATERIALS AND METHODS}

\section{Mung bean pancake preparation}

Schematic diagram of mung bean pancake preparation was shown as Fig. 1. Dry mung bean (Phaseolus aureus Leguminosae), dry soybean (Glycine max Leguminosae), five kinds of vegetables including mung bean-sprout, fiddlehead fern (Pteridium aquilium Kuhn), balloon flower (Platycodon grandiflorum), green onion (Allium cepa Liliaceae), red and green pepper (Capsicum annuum L.) were purchased in the local food market, Busan, Korea. Boneless, skinless pork shank was trimmed of external fat and connective tissue and coarsely ground in a chopper (HMC-150T, Han-Il, Bucheon, Korea). Pretreated skinless squid (Ommastrephes sloani Pacificus) mantle and five kinds of vegetables, as shown 


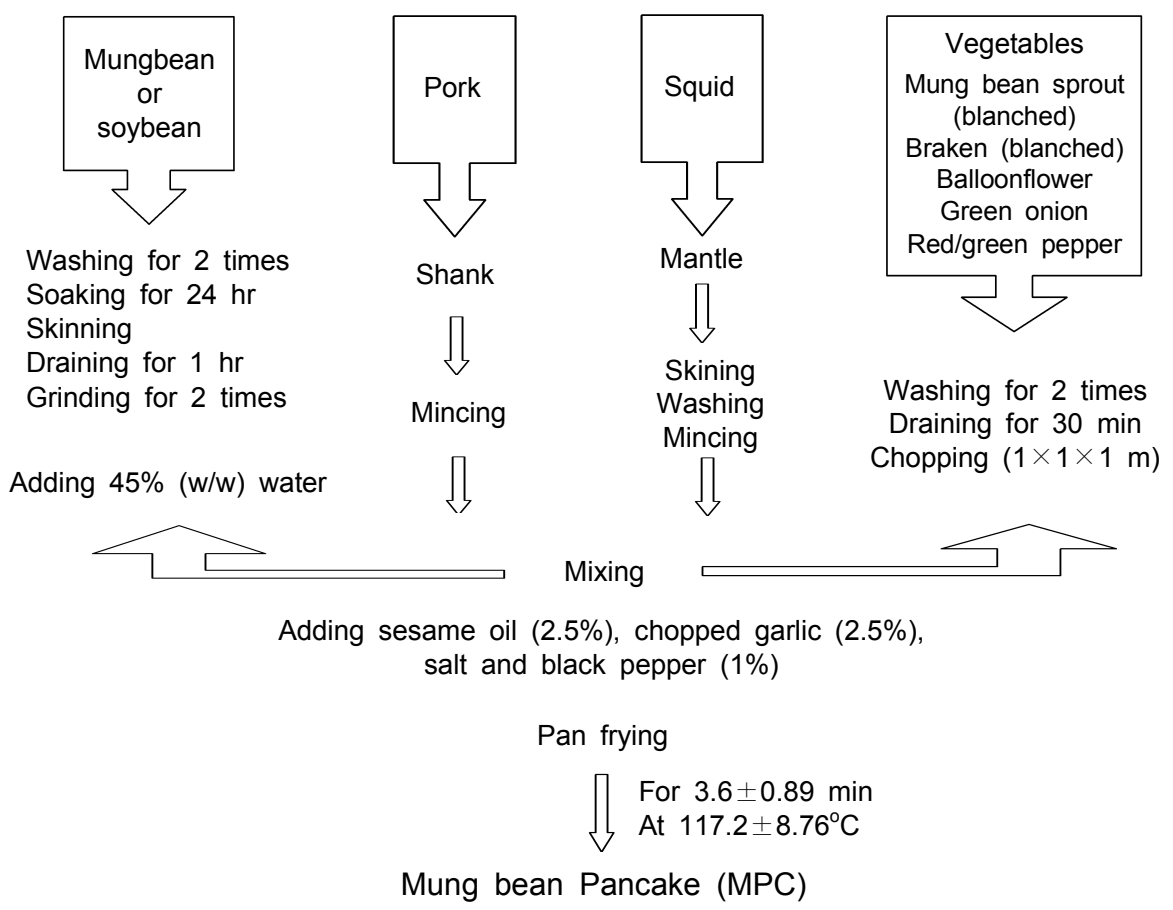

Fig. 1. Schematic diagram of traditional and modified mung bean pancake (MPC) preparation.

Fig. 1, were also chopped. All ingredients of MPC were weighed and added to the formulation by simplex centroid design (Fig. 2, Table 1). All seasonings of $2.5 \%$ $(\mathrm{w} / \mathrm{w})$ of chopped garlic, $2.5 \%(\mathrm{w} / \mathrm{w})$ of sesame oil, and $1 \%(\mathrm{w} / \mathrm{w})$ of salt- pepper mixture (50:1) were also added, then they were thoroughly mixed.

The mixture from each formulation was weighed to provide individual MPC pieces $(50 \pm 1 \mathrm{~g}$ per piece), shaped into the circular stainless steel $(8 \mathrm{~cm}$ diameter, $0.5 \mathrm{~cm}$ height) and pan fried in soybean oil at $117.2 \pm$

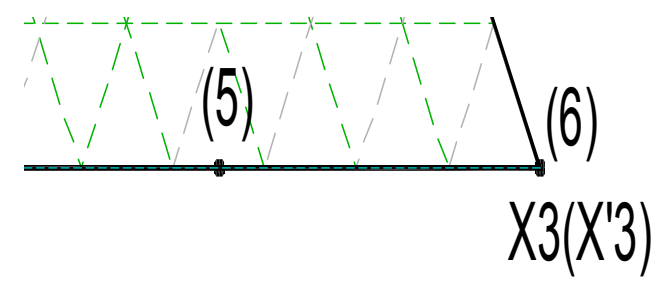

\section{rdesign plot in amounts}

Fig. 2. Three component simplex centroid design. X1 (mungbean) ranged from 0.3 to 1.0 and $\mathrm{X} 2$ (pork) and X3 (vegetables) ranged from 0.0 to 0.7 for traditional mungbean pan cake. X'1 (pork), X'2 (squid) and X'3 (soybean) ranged from 0.0 to 1.0 for modified mung bean pancake. $8.8^{\circ} \mathrm{C}$ for $3.6 \pm 0.9$ minutes using automatic double pan (HPT-500, Eastern Magic, Seoul, Korea). Pan-fried MPC were immediately served to consumers and tested for texture profile analysis. Consumer acceptability test and texture profile analyses were finished within 20 minutes. For nutritional evaluation, fried MPC were

Table 1. Mixture ratio of ten formulations in a three component simplex centroid design ${ }^{1)}$

\begin{tabular}{|c|c|c|c|c|c|c|}
\hline \multirow{3}{*}{$\begin{array}{l}\text { Formulation } \\
\text { number }^{2)}\end{array}$} & \multicolumn{6}{|c|}{ Ingredient ratio of mung bean pancake } \\
\hline & \multicolumn{3}{|c|}{ Traditional $\mathrm{MPC}^{3)}$} & \multicolumn{3}{|c|}{ Modified MPC ${ }^{4}$} \\
\hline & $\begin{array}{l}\mathrm{MB} \\
\left(\mathrm{x}_{1}\right)\end{array}$ & $\begin{array}{c}\text { Pork } \\
\left(\mathrm{x}_{2}\right)\end{array}$ & $\begin{array}{c}\text { Veg. }{ }^{5)} \\
\left(x_{3}\right)\end{array}$ & $\begin{array}{l}\text { Pork } \\
\left(\mathrm{x}^{\prime}{ }_{1}\right)\end{array}$ & $\begin{array}{l}\text { Squid } \\
\left(\mathrm{x}^{\prime}{ }_{2}\right)\end{array}$ & $\begin{array}{c}\mathrm{SB} \\
\left(\mathrm{x}^{\prime}{ }_{3}\right)\end{array}$ \\
\hline 1 & 1.00 & 0.00 & 0.00 & 1.00 & 0.00 & 0.00 \\
\hline 2 & 0.65 & 0.35 & 0.00 & 0.50 & 0.50 & 0.00 \\
\hline 3 & 0.65 & 0.00 & 0.35 & 0.50 & 0.00 & 0.50 \\
\hline 4 & 0.30 & 0.70 & 0.00 & 0.00 & 1.00 & 0.00 \\
\hline 5 & 0.30 & 0.35 & 0.35 & 0.00 & 0.50 & 0.50 \\
\hline 6 & 0.30 & 0.00 & 0.70 & 0.00 & 0.00 & 1.00 \\
\hline 7 & 0.53 & 0.23 & 0.23 & 0.33 & 0.33 & 0.33 \\
\hline 8 & 0.77 & 0.12 & 0.12 & 0.67 & 0.17 & 0.17 \\
\hline 9 & 0.42 & 0.47 & 0.12 & 0.17 & 0.67 & 0.17 \\
\hline 10 & 0.42 & 0.12 & 0.47 & 0.17 & 0.17 & 0.67 \\
\hline
\end{tabular}

${ }^{1)}$ Experimental runs were performed in random order by MINITAB (Minitab, 2000).

${ }^{2)}$ Formulation numbers correspond to the numbers shown in Fig. 2.

${ }^{3)} \mathrm{MB}$ (mung bean) ranged from 0.3 to 1.0 , pork and vegetables ranged from 0.0 to 0.7 .

${ }^{4)}$ Pork, squid and SB (soybean) ranged from 0.0 to 1.0 .

${ }^{5)}$ Vegetables were assorted with mung bean sprouts, fiddlehead fern, balloon flower, green onion, green and red pepper as a weight ratio of $5: 5: 5: 5: 2$. 
wrapped with vinyl wrap and kept in a deep-freezer within 2 days.

\section{Experimental design}

A three-component constrained simplex centroid mixture design (10) was used at the first stage. The mixture consisted of three components of mung bean (X1), pork (X2), and assorted vegetables (X3). Component proportions were expressed as fractions of mixture and the sum of the proportions $(\mathrm{X} 1+\mathrm{X} 2+\mathrm{X} 3)$ equaled 1.0. The mixture ratio of mung bean used as the basic ingredient of batter was constrained to $\mathrm{X} 1 \geq 0.3$. At the second stage, modified MPC was prepared by partial replacement of the pork of traditional MPC with a mixture of pork, squid and soybean, in order to reduce calories and improve the composition of fatty acids. Simplex centroid design with mixture components of pork (X'1), squid (X'2), soybean (X'3) was used. The practical range of proportions of component variables was established (Fig. 2, Table 1). Ten formulations were tested for each stage.

\section{Consumer acceptability test}

A consumer acceptability questionnaire test with 9-hedonic scale $(1=$ dislike extremely, $5=$ neither dislike nor like, 9=like extremely) was used, and five sensory attributes of overall acceptability, appearance, color, flavor, hardness were measured. Untrained consumers consisted of 34 male students from Yeonchun middle school, Busan, Korea. They were (1) between 14 16 years old, (2) not allergic to pork, mung bean, or soybean oil, and (3) were potent consumers of new Korean fast food products. Because most of the testers had not participated in a consumer acceptability test, they were briefly instructed on the testing procedures. The tests were conducted at one time from 11:00 12:00 a.m. Freshly prepared mung bean pancakes were presented to the testers (1 piece per formulation) in white polyethylene dishes coded with random numbers on a table lined with white paper. Water was provided for testers in order to minimize any residual effect between samples.

\section{Texture profile analysis}

Texture profiles of MPC were obtained by two bite compression test using a texture analyzer (TA-XT2i, Stable Microsystem, Godalming, England) connected to a computer. Hardness, adhesiveness, springiness, cohesiveness, gumminess, chewiness, and resilience were analyzed from force-time curve according to Borne (11) and Szczesniak (12). Texture analyses of each formulation were finished within 10 minutes, the same time frame in which the consumer acceptability tests were ended.

Nutritional evaluation

Proximate composition analyses (moisture, total ash, crude protein, and crude lipid) were carried on according to the AOAC method (13). Degree of gelatinization was determined by the method in the Handbook of Food Analysis (14). Protein digestibility and C-PER (Computed Protein Efficiency Ratio) were calculated by AOAC methods (15). TBA value was measured by the Turner et al. method (16) and developed brown-pigment was checked using the Chung and Toyomizu method (17).

\section{Statistical analysis}

Multiple regression analysis (18) was used to fit a quadratic canonical polynomial model (19) as follows.

$$
\hat{Y}_{k}=b_{1} X_{1}+b_{2} X_{2}+b_{3} X_{3}+b_{12} X_{12}+b_{13} X_{13}+b_{23} X_{23}
$$

where $Y_{k}$ is the $k$-the predicted response variables (either overall acceptability, appearance, color, flavor or hardness), $X_{i}$ is component (X1: mung bean, $\mathrm{X} 2$ : pork, and $\mathrm{X} 3$ : assorted vegetables for traditional MPC, $\mathrm{X}^{\prime} 1$ : pork, X'2: squid, and X'3: soybean for modified MPC), $b_{i}$ ( $i$ $=1,2,3)$ or $b_{i j}(i<j)$ is a corresponding parameter for regression coefficients.

Cox response plot, three dimensional surface plots, contour plots, optimization response curves and overlaid contour plots were generated from multiple regression equations.

\section{RESULTS AND DISCUSSION}

\section{Consumer acceptability test}

A multiple regression equation for traditional and modified MPCs was developed in quadratic canonical polynomial models using response surface methodology. These were statistically significant at the level of p-value 0.001 (Table 2, Table 3). The validity of these multiple regression equations was proved by normal probability plots of residuals. On the basis of these regression equation Cox response plots, three-dimensional surface plots, contour plots and overlaid contour plots were generated (Fig. 3 Fig. 6).

\section{Overall acceptability}

Pork (regression coefficient, $\mathrm{b}_{2}=6.420$ ) and mung bean $\left(b_{1}=5.016\right)$ strongly influenced overall acceptability of traditional MPC, while vegetables $\left(b_{3}=0.462\right)$ had a minor effect (Table 2). The overall acceptability of a food is not only based on intrinsic sensory characteristics, but also the degree to which product meets sensory and hedonic expectations (20). The sensory score of overall acceptability gradually rose as the mixture ratio of pork of traditional MPC was increased. The addition of vegetables and mung bean to MPC formulations decreased overall acceptability scores in a quadratic equation (Fig. $3 \mathrm{~A})$. This kind of optimization of mixture ratio is needed 
Table 2. Regression for each dependent sensory attribute of consumer acceptability of traditional MPC in the teenager group ${ }^{1)}$

\begin{tabular}{llcc}
\hline Dependent variables & Predictive models & $\mathrm{p}$-value \\
\hline Overall acceptability & $\hat{Y}_{1}=5.016 \mathrm{x}_{1}{ }^{3}+6.420 \mathrm{x}_{2}+0.462 \mathrm{x}_{3}+0.392 \mathrm{x}_{1} \mathrm{x}_{2}+10.557 \mathrm{x}_{1} \mathrm{x}_{3}+7.598 \mathrm{x}_{2} \mathrm{x}_{3}$ & $<0.001$ \\
Appearance & $\hat{Y}_{2}=3.860 \mathrm{x}_{1}+5.013 \mathrm{x}_{2}-0.883 \mathrm{x}_{3}+2.524 \mathrm{x}_{1} \mathrm{x}_{2}+18.431 \mathrm{x}_{1} \mathrm{x}_{3}+6.918 \mathrm{x}_{2} \mathrm{x}_{3}$ & $<0.001$ \\
Color & $\hat{Y}_{3}=3.756 \mathrm{x}_{1}+3.578 \mathrm{x}_{2}+0.551 \mathrm{x}_{3}+4.786 \mathrm{x}_{1} \mathrm{x}_{2}+16.416 \mathrm{x}_{1} \mathrm{x}_{3}+9.268 \mathrm{x}_{2} \mathrm{x}_{3}$ & $<0.001$ \\
Flavor & $\hat{Y}_{4}=5.366 \mathrm{x}_{1}+7.243 \mathrm{x}_{2}+3.148 \mathrm{x}_{3}-1.356 \mathrm{x}_{1} \mathrm{x}_{2}+3.976 \mathrm{x}_{1} \mathrm{x}_{3}+7.960 \mathrm{x}_{2} \mathrm{x}_{3}$ & $<0.001$ \\
Hardness & $\hat{Y}_{5}=5.291 \mathrm{x}_{1}+7.895 \mathrm{x}_{2}+1.270 \mathrm{x}_{3}-2.724 \mathrm{x}_{1} \mathrm{x}_{2}+7.616 \mathrm{x}_{1} \mathrm{x}_{3}+6.708 \mathrm{x}_{2} \mathrm{x}_{3}$ & $<0.001$ \\
\hline
\end{tabular}

${ }^{1)}$ Based on 34 observations. Consumer scores were based on a 9 point hedonic scale $(1=$ dislike extremely, $5=$ neither like nor dislike and 9=like extremely).

${ }^{2}$ Statistically siginificant at the level of p-value represented.

${ }^{3)} \mathrm{x}_{1}$ : mungbean, $\mathrm{x}_{2}$ : pork, $\mathrm{x}_{3}$ : vegetables.

Table 3. Regression for each dependent sensory attribute of modified MPC in the teenager group from consumer acceptability test $^{1)}$

\begin{tabular}{|c|c|c|}
\hline Dependent variables & Predictive models & p-value ${ }^{2)}$ \\
\hline Overall acceptability & $\hat{Y}_{1}=6.112 \mathrm{x}_{1}{ }_{1}{ }^{3)}+6.222 \mathrm{x}_{2}{ }_{2}+4.604 \mathrm{x}_{3}{ }_{3}+0.061 \mathrm{x}_{1}{ }_{1} \mathrm{x}_{2}{ }_{2}+1.296 \mathrm{x}_{1}{ }_{1} \mathrm{x}^{\prime}{ }_{3}+1.986 \mathrm{x}_{2}{ }_{2} \mathrm{x}_{3}{ }_{3}$ & $<0.001$ \\
\hline Appearance & $\hat{Y}_{2}=6.019 \mathrm{x}_{1}{ }_{1}+5.021 \mathrm{x}_{2}{ }_{2}+4.494 \mathrm{x}_{3}{ }_{3}+1.975 \mathrm{x}_{1}{ }_{1} \mathrm{x}^{\prime}{ }_{2}-0.961 \mathrm{x}^{\prime}{ }_{1} \mathrm{x}_{3}{ }_{3}+1.750 \mathrm{x}_{2}{ }_{2} \mathrm{x}{ }_{3}{ }_{3}$ & $<0.001$ \\
\hline Color & $\hat{Y}_{3}=6.100 \mathrm{x}_{1}{ }_{1}+5.330 \mathrm{x}_{2}{ }_{2}+4.341 \mathrm{x}_{3}{ }_{3}+0.042 \mathrm{x}_{1}{ }_{1} \mathrm{x}^{\prime}{ }_{2}+1.357 \mathrm{x}^{\prime}{ }_{1} \mathrm{X}^{\prime}{ }_{3}+2.288 \mathrm{x}_{2}{ }_{2} \mathrm{x}_{3}{ }_{3}$ & $<0.001$ \\
\hline Flavor & $\hat{Y}_{4}=5.876 \mathrm{x}{ }_{1}+5.860 \mathrm{x}{ }_{2}+5.029 \mathrm{x}{ }_{3}+2.646 \mathrm{x}_{1}{ }_{1} \mathrm{x}_{2}{ }_{2}+0.865 \mathrm{x}{ }_{1}{ }_{1}{ }^{\prime}{ }_{3}+2.597 \mathrm{x}_{2}{ }_{2} \mathrm{x}_{3}{ }_{3}$ & $<0.001$ \\
\hline Hardness & $\hat{Y}_{5}=6.051 \mathrm{x}{ }_{1}+6.101 \mathrm{x}{ }_{2}+4.366 \mathrm{x}{ }_{3}+1.973 \mathrm{x}_{1}{ }_{1} \mathrm{x}_{2}{ }_{2}+2.855 \mathrm{x}{ }_{1}{ }_{1}{ }^{\prime}{ }_{3}+1.427 \mathrm{x}{ }_{2} \mathrm{X}_{3}{ }_{3}$ & $<0.001$ \\
\hline
\end{tabular}

${ }^{1)}$ Based on 34 observations. Consumer scores were based on a 9 point hedonic scale $(1=$ dislike extremely, $5=$ neither like nor dislike and 9=like extremely).

${ }^{2)}$ Statistically siginificant at the level of p-value represented.

${ }^{3)} \mathrm{x}_{1}{ }_{1}$ : pork, $\mathrm{x}_{2}$ : squid, $\mathrm{x}_{3}{ }_{3}$ : soybean.

(A)

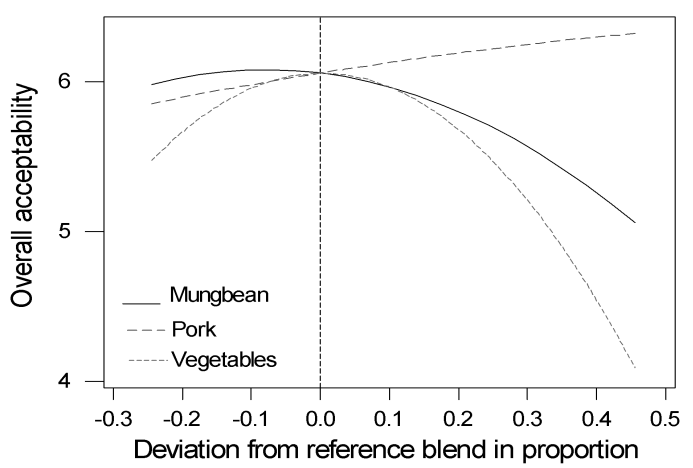

(B)

\begin{tabular}{cc||ccc} 
New & Mungbean & Pork & Vegetables \\
$D$ & Hi & 1.0000 & 0.70 & 0.7000 \\
0.63748 & Cur & {$[0.3407]$} & {$[0.4876]$} & {$[0.1717]$} \\
& Lo & 0.30 & 0.0 & 0.0 \\
\hline \hline $\begin{array}{c}\text { Overall } \\
\text { acceptability } \\
\text { Maximum } \\
y=6.2371\end{array}$ & & & \\
$d=0.65464$ & & & & \\
\hline
\end{tabular}

Fig. 3. Cox response plot (A) and response optimization curve (B) for overall acceptability of traditional MPC in teenagers group. ' 0.0 ' is the point that mixture ratio of mungbean : pork : vegetables is $0.54: 0.23: 0.23$. The optimum ratio of mungbean : pork : vegetables is 0.34:0.49:0.17. Numbers $(1 \sim 10)$ represent ten formulations and correspond to the numbers in Table 1 .

(A)

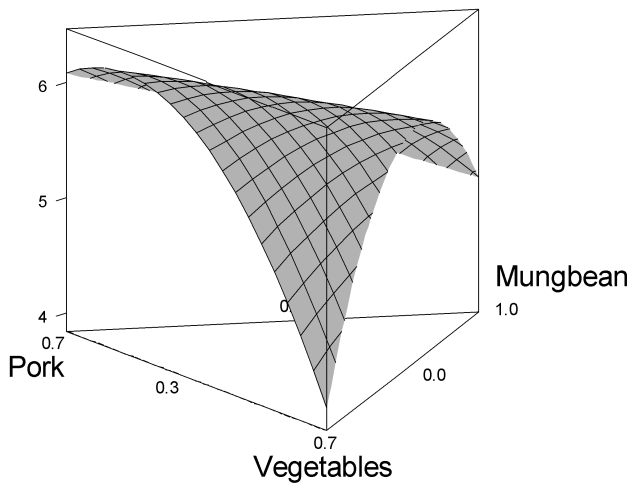

(B)

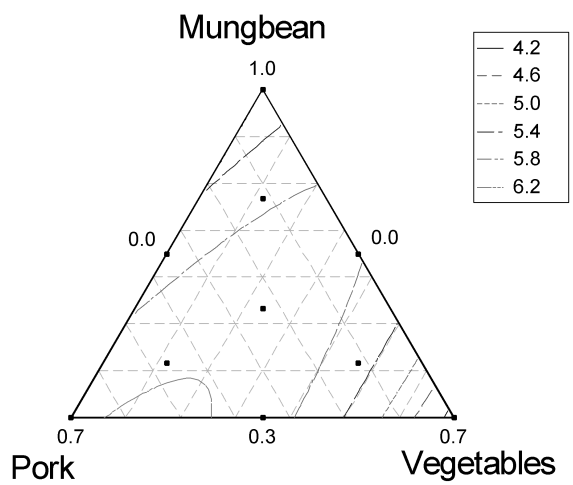

Fig. 4. Surface plot (A) and contour plot (B) for overall acceptability of traditional MPC in teenagers group.

in the food industry during initial stage of product development $(21,22)$; while it is impossible to optimize the maximum point of all mixture ingredients, it can be possible to at least approach it (9). Therefore, desirability 
function approach suggested the optimum mixture ratios were 0.34:0.49:0.17 of mung bean : pork : vegetables for traditional MPC (Fig. 3B). An overall acceptability score could be expected to be 6.2 and the desirability function to be 0.65 . It (0.65) means relative value of expected sensory score when maximum value of sensory score, 9 is 1 of desirability function (18). Also three dimensional surface plot and contour plot showed the maximum point of overall acceptability at same mixture ratio (Fig. 4).

Modified MPC was prepared by partial replacement of the pork of traditional MPC with mixture of pork, squid and soybean, in order to reduce calories and improve the composition of fatty acids of MPC. The addition of pork and squid had gradually increased the overall acceptability scores, but the addition of soybean sharply decreased the sensory scores (Fig. 5A). It could be expected the optimum mixture ratios were 0.21:0.66 $: 0.13$ of pork : squid : soybean for modified MPC. The predicted overall acceptability score was 6.2 (desirability function $=0.65$ ), the same score as traditional MPC (Fig. $5 B)$. The regression coefficient of pork $\left(b_{1}=6.112\right)$ and squid $\left(b_{2}=6.222\right)$ were higher than that of soybean $\left(b_{3}=4.604\right)$ for modified MPC (Table 3 ). The three dimensional surface plot and contour plot of modified MPC were generated (Fig. 6).

\section{Appearance and color}

Appearances include sensory attributes such as color, shape, and size, as well as more complex attributes such as surface texture and structural uniformity $(20,23)$. Pork $\left(b_{1}=5.013\right)$ and mung bean $\left(b_{2}=3.860\right)$ had greater influence on the appearance of traditional MPC compared to the effect of vegetables $\left(b_{3}=-0.883\right)$ for traditional MPC (Table 2). As noted by Cardello (20), both color and particle size of ingredients affect visual and textural appearances of extended patties. This study revealed that, although mung bean particles were homogenously dispersed and suitably small to allow good binding of water, fat and pork pieces during preparation, particles were large enough to be seen easily at the surface of MPC (24). Appearance attributes indicated that the MPC with $63 \%$ mung bean still had a smoother-looking outer surface, but at the lower mung bean level, the appearance scores were sharply decreased for the traditional MPC.
(A)

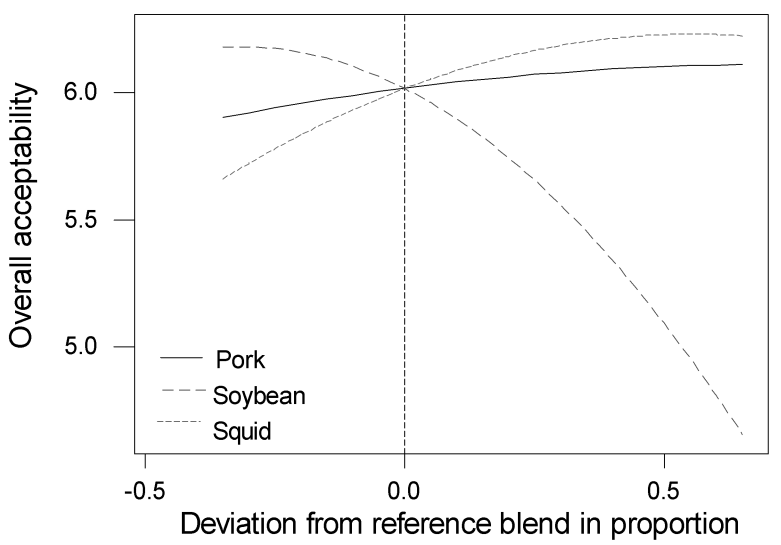

(B)

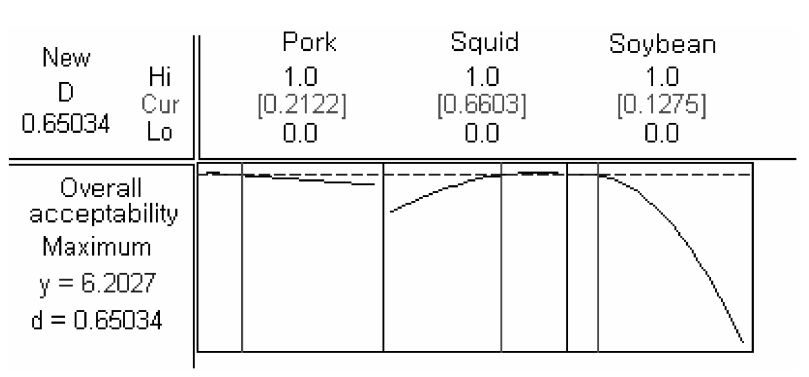

Fig. 5. Cox response plot (A) and response optimization curve (B) for overall acceptability of modified MPC in teenagers group. ' 0.0 ' is the point that the mixture ratio of pork: squid : soybean is $0.33: 0.33: 0.33$. The optimum ratio of pork: squid : soybean is $0.21: 0.66: 0.13$.

(A)

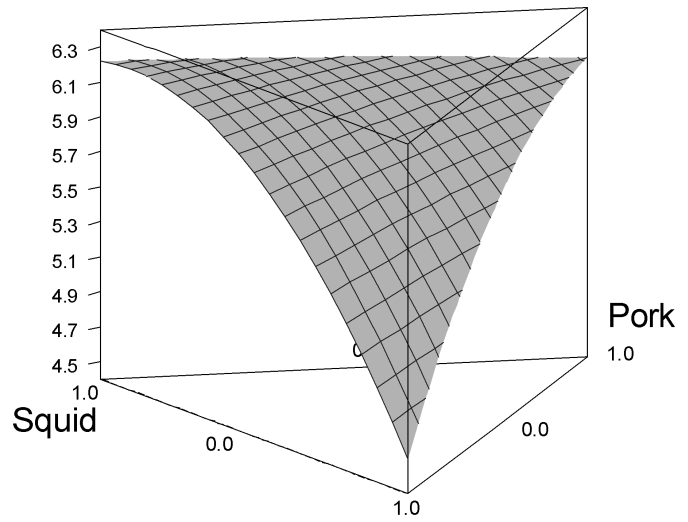

(B)

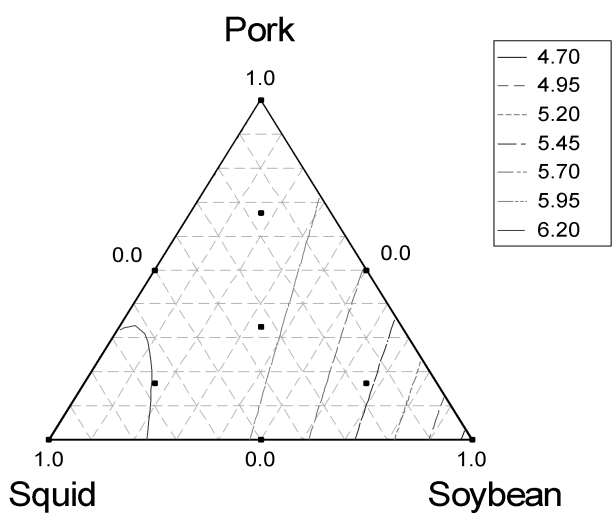

Fig. 6. Surface plot (A) and contour plot (B) for overall acceptability of modified MPC in teenagers group. 
Table 4. Optimum mixture ratio and predicted sensory scores of traditional and modified MPC from consumer acceptability test $^{1)}$

\begin{tabular}{|c|c|c|c|c|c|}
\hline & \multirow{2}{*}{ Sensory attributes } & \multicolumn{3}{|c|}{ Optimum ratio } & \multirow{2}{*}{$\begin{array}{c}\text { Predicted sensory } \\
\text { scores }\end{array}$} \\
\hline & & Mungbean & Pork & Vegetables & \\
\hline \multirow{7}{*}{ Traditional MPC } & Overall acceptability & 0.34 & 0.49 & 0.17 & 6.2 \\
\hline & Appearance & 0.61 & 0.03 & 0.37 & 6.4 \\
\hline & Color & 0.55 & 0.07 & 0.38 & 6.4 \\
\hline & Flavor & 0.31 & 0.51 & 0.18 & 6.7 \\
\hline & Hardness & 0.30 & 0.62 & 0.08 & 6.6 \\
\hline & Sencory attrihuter & \multicolumn{3}{|c|}{ Optimum ratio } & Predicted sensory \\
\hline & Sensory attributes & Pork & Squid & Soybean & scores \\
\hline \multirow{5}{*}{ Modified MPC } & Overall acceptability & 0.21 & 0.66 & 0.13 & 6.2 \\
\hline & Appearance & 0.71 & 0.29 & 0.00 & 6.1 \\
\hline & Color & 0.59 & 0.29 & 0.12 & 5.8 \\
\hline & Flavor & 0.48 & 0.48 & 0.04 & 6.5 \\
\hline & Hardness & 0.48 & 0.48 & 0.04 & 6.5 \\
\hline
\end{tabular}

${ }^{1)}$ Based on 34 observations.

Mung bean $\left(b_{1}=3.756\right)$ and pork $\left(b_{2}=3.578\right)$ had a similar effect on color attributes of traditional MPC (Table 2), while the vegetables $\left(b_{3}=0.551\right)$ had a minor effect on color. As the pork ratio was increased, color acceptability was decreased sharply. For modified MPC, the addition of soybean decreased color acceptability. The optimum mixture ratios of traditional and modified MPC were shown in Table 4. Cox response plot, surface plot and contour plot were not shown.

\section{Flavor and hardness}

The flavor acceptability generally decreased with increased amounts of mung bean $\left(b_{1}=5.366\right)$ and flavor acceptability became lower with decreased amounts of pork $\left(b_{2}=7.243\right)$. The hardness acceptability decreased with increased amounts of mung bean for traditional MPC (Table 2). The addition of soybean gave a sharp decrease on the flavor and texture attributes for modified MPC and the effect of soybean was a slightly bigger than other sensory attributes (Table 3). The optimum mixture ratios of traditional and modified MPC were shown in Table 4.

\section{Texture profile analysis}

A multiple regression equation of textural profile for traditional and modified MPC was developed in quadratic canonical polynomial models by using response surface methodology, these were statistically significant at the level of p-value 0.001 (Table 5, 6). The validity of these multiple regression equation was proved by normal probability plot of residuals. As relative proportion of mung bean and pork increased, hardness and adhesiveness were increased, while springiness, cohesiveness, gumminess, chewiness and resilience were significantly decreased. But in the case of MPC with a higher proportion of vegetables, most of the textural attributes were lower than those of traditional MPC. Modified MPC containing minced squid meat showed high textural attributes, but the addition of soybean lowered hardness, cohesiveness and gumminess. These results corresponded with other reports by Shin and Woo (25), it might be due to the hydrolysis of starch granules by $\alpha$-amylase in soybean (25).

\section{Nutritional evaluation}

The nutritional evaluation of MPC with an optimum mixture ratio is shown in Table 7. Modified MPC with squid and soybean improved the gelatinization degree of starch, likely caused by the activity of $\alpha$-amylase in

Table 5. Regression for each texture attribute of traditional $\mathrm{MPC}^{1)}$

\begin{tabular}{llcc}
\hline Dependent variables & \multicolumn{1}{c}{ Predictive models } & $\mathrm{p}$-value ${ }^{2)}$ \\
\hline Hardness & $\hat{Y}^{\prime}{ }_{1}=2830 \mathrm{x}_{1}{ }^{3)}+2755 \mathrm{x}_{2}+497 \mathrm{x}_{3}-2948 \mathrm{x}_{1} \mathrm{x}_{2}-2523 \mathrm{x}_{1} \mathrm{x}_{3}-1931 \mathrm{x}_{2} \mathrm{x}_{3}$ & $<0.001$ \\
Adhesiveness & $\hat{Y}^{\prime}{ }_{2}=-21.10 \mathrm{x}_{1}-17.04 \mathrm{x}_{2}-95.98 \mathrm{x}_{3}+41.50 \mathrm{x}_{1} \mathrm{x}_{2}+82.47 \mathrm{x}_{1} \mathrm{x}_{3}+36.59 \mathrm{x}_{2} \mathrm{x}_{3}$ & $<0.001$ \\
Springiness & $\hat{Y}^{\prime}{ }_{3}=0.349 \mathrm{x}_{1}+0.496 \mathrm{x}_{2}+0.303 \mathrm{x}_{3}-0.436 \mathrm{x}_{1} \mathrm{x}_{2}-0.508 \mathrm{x}_{1} \mathrm{x}_{3}-0.151 \mathrm{x}_{2} \mathrm{x}_{3}$ & $<0.001$ \\
Cohesiveness & $\hat{Y}^{\prime}{ }_{4}=0.218 \mathrm{x}_{1}+0.308 \mathrm{x}_{2}+0.192 \mathrm{x}_{3}-0.289 \mathrm{x}_{1} \mathrm{x}_{2}-0.220 \mathrm{x}_{1} \mathrm{x}_{3}-0.008 \mathrm{x}_{2} \mathrm{x}_{3}$ & $<0.001$ \\
Gumminess & $\hat{Y}^{\prime}{ }_{5}=632 \mathrm{x}_{1}+820 \mathrm{x}_{2}+207 \mathrm{x}_{3}-1343 \mathrm{x}_{1} \mathrm{x}_{2}-1092 \mathrm{x}_{1} \mathrm{x}_{3}-567 \mathrm{x}_{2} \mathrm{x}_{3}$ & $<0.001$ \\
Chewiness & $\hat{Y}^{\prime}{ }_{6}=244.7 \mathrm{x}_{1}+377.1 \mathrm{x}_{2}+103.3 \mathrm{x}_{3}-744.0 \mathrm{x}_{1} \mathrm{x}_{2}-584.2 \mathrm{x}_{1} \mathrm{x}_{3}-326.8 \mathrm{x}_{2} \mathrm{x}_{3}$ & $<0.001$ \\
Resilience & $\hat{Y}^{\prime}{ }_{7}=0.064 \mathrm{x}_{1}+0.084 \mathrm{x}_{2}+0.049 \mathrm{x}_{3}-0.087 \mathrm{x}_{1} \mathrm{x}_{2}-0.078 \mathrm{x}_{1} \mathrm{x}_{3}-0.017 \mathrm{x}_{2} \mathrm{x}_{3}$ & $<0.001$ \\
\hline
\end{tabular}

\footnotetext{
${ }^{1)}$ Based on 10 observations.

${ }^{2)}$ Statistically significant at the level of p-value represented.

${ }^{3)} \mathrm{x}_{1}$ : mungbean, $\mathrm{x}_{2}$ : pork, $\mathrm{x}_{3}$ : vegetables.
} 
Table 6. Regression for each texture attribute of modified MPC ${ }^{1)}$

\begin{tabular}{|c|c|c|}
\hline Dependent variables & Predictive models & p-value ${ }^{2)}$ \\
\hline Hardness & $\hat{Y}_{1}^{\prime}=1655 \mathrm{x}_{1}^{\prime}{ }_{1}^{3)}+1082 \mathrm{x}_{2}{ }_{2}+864 \mathrm{x}_{3}{ }_{3}-443 \mathrm{x}_{1}{ }_{1} \mathrm{x}_{2}{ }_{2}-1619 \mathrm{x}_{1}{ }_{1} \mathrm{x}_{3}{ }_{3}-285 \mathrm{x}_{2}{ }_{2} \mathrm{x}_{3}{ }_{3}$ & $<0.001$ \\
\hline Adhesiveness & $\hat{Y}^{\prime}{ }_{2}=-13.59 \mathrm{x}_{1}{ }_{1}-11.63 \mathrm{x}_{2}{ }_{2}-52.85 \mathrm{x}_{3}{ }_{3}+6.51 \mathrm{x}_{1}{ }_{1} \mathrm{x}_{2}{ }_{2}+21.66 \mathrm{x}_{1}{ }_{1} \mathrm{x}^{\prime}{ }_{3}+37.65 \mathrm{x}_{2}{ }_{2} \mathrm{x}_{3}{ }_{3}$ & $<0.001$ \\
\hline Springiness & $\hat{Y}_{3}{ }_{3}=0.293 \mathrm{x}_{1}+0.345 \mathrm{x}_{2}+0.159 \mathrm{x}_{3}{ }_{3}-0.020 \mathrm{x}_{1}{ }_{1} \mathrm{x}_{2}{ }_{2}-0.109 \mathrm{x}_{1}{ }_{1} \mathrm{X}_{3}{ }_{3}+0.005 \mathrm{x}_{2}{ }_{2} \mathrm{x}_{3}{ }_{3}$ & $<0.001$ \\
\hline Cohesiveness & $\hat{Y}_{4}{ }_{4}=0.182 \mathrm{x}_{1}{ }_{1}+0.233 \mathrm{x}_{2}{ }_{2}+0.150 \mathrm{x}{ }_{3}{ }_{3}-0.056 \mathrm{x}^{\prime}{ }_{1} \mathrm{x}^{\prime}{ }_{2}-0.039 \mathrm{x}^{\prime}{ }_{1} \mathrm{x}_{3}{ }_{3}+0.018 \mathrm{x}{ }_{2}{ }_{2} \mathrm{x}^{\prime}{ }_{3}$ & $<0.001$ \\
\hline Gumminess & $\hat{Y}_{5}{ }_{5}=296.7 \mathrm{x}{ }_{1}+246.3 \mathrm{x}_{2}{ }_{2}+130.0 \mathrm{x}{ }_{3}-127.9 \mathrm{x}{ }_{1}{ }_{1} \mathrm{x}^{\prime}{ }_{2}-253.2 \mathrm{x}^{\prime}{ }_{1} \mathrm{x}_{3}{ }_{3}-48.1 \mathrm{x}_{2}{ }_{2} \mathrm{x}^{\prime}{ }_{3}$ & $<0.001$ \\
\hline Chewiness & $\hat{Y}_{6}{ }_{6}=87.30 \mathrm{x}_{1}{ }_{1}+85.23 \mathrm{x}_{2}{ }_{2}+22.18 \mathrm{x}{ }_{3}{ }_{3}-36.78 \mathrm{x}_{1}{ }_{1} \mathrm{x}^{\prime}{ }_{2}-97.15 \mathrm{x}_{1}{ }_{1} \mathrm{x}_{3}{ }_{3}-31.39 \mathrm{x}_{2}{ }_{2} \mathrm{x}^{3}{ }_{3}$ & $<0.001$ \\
\hline Resilience & $\hat{Y}_{7}^{\prime}=0.043 \mathrm{x}_{1}{ }_{1}+0.060 \mathrm{x}_{2}{ }_{2}+0.036 \mathrm{x}_{3}{ }_{3}-0.017 \mathrm{x}_{1}{ }_{1} \mathrm{x}^{\prime}{ }_{2}-0.000 \mathrm{x}^{\prime}{ }_{1} \mathrm{x}_{3}{ }_{3}-0.021 \mathrm{x}_{2}{ }_{2} \mathrm{x}^{\prime}{ }_{3}$ & $<0.001$ \\
\hline
\end{tabular}

${ }^{1)}$ Based on 10 observations.

${ }^{2)}$ Statistically significant at the level of p-value represented.

${ }^{3)} \mathrm{x}_{1}{ }_{1}$ : pork, $\mathrm{x}_{2}{ }_{2}$ : squid, $\mathrm{x}_{3}$ : soybean.

Table 7. Nutritional evaluation of MPC with optimum mixture ratio from consumer acceptability test ${ }^{1)}$

\begin{tabular}{lcrc}
\hline & Traditional MPC & Modified MPC & p-value \\
\hline Degree of gelatization (\%) & $67.77 \pm 13.45$ & $72.60 \pm 2.08$ & $\mathrm{NS}^{3)}$ \\
Protein digestibility (\%) & $89.40 \pm 0.51$ & $88.27 \pm 1.15$ & $\mathrm{NS}$ \\
C-PER & $1.97 \pm 0.00$ & $1.97 \pm 0.00$ & $\mathrm{NS}$ \\
TBA value (O.D. $\times 100)$ & $35.61 \pm 3.47$ & $44.37 \pm 0.78$ & $<0.001$ \\
Brown-pigment & & & $<0.001$ \\
Hydrophilic (O.D. $\times 100)$ & $0.21 \pm 0.03$ & $0.37 \pm 0.05$ & $<0.010$ \\
Lipophilic (O.D. $\times 100)$ & $5.49 \pm 0.17$ & $6.13 \pm 1.60$ & \\
\hline
\end{tabular}

${ }^{1)}$ Value represents mean \pm standard deviation of triplicate analysis.

${ }^{2)}$ C-PER: Computed protein efficiency ratio.

${ }^{3)} \mathrm{NS}$ : Not significant.

soybean $(25,26)$. Modified MPC had a competitive protein digestibility and protein efficiency ratio (C-PER) compared to traditional MPC even though modified MPC showed the higher values for TBA value and brown pigment which could lead the decreased digestibility or PER (27). Brown pigment has an adverse effect on protein quality, and the higher levels of lipophilic brown pigment was formed than hydrophilic brown pigment in both MPC as shown as Table 7.

\section{REFERENCES}

1. Lee SG, Jang MS. 2001. Standardization of preparation methods for Hwajeun (1). Korean J Soc Food Cookery Sci 17: 237-246.

2. Chang MJ, Cho MS. 2000. Recognition and preference to Korean traditional food of foreign visitors in Korea. Korean J Dietary Culture 15: 215-223.

3. Koo SJ. 2001. The future prospect of food \& cookery science of Korea. J Korean Food Cookery Sci 17: 165-195.

4. Ro SB, Shin AS, Kil JO. 2001. A study on the traditional fast food development of college students in Busan. Korean J Dietary Culture 16: 81-88.

5. Kang SH, Ryu GH. 2002. Analysis of traditional process for Yukwa making, a Korean puffed rice snack. Korean J Food Sci Technol 34: 818-823.

6. Lee SM, Cho JS. 2001. Sensory and mechanical characteristics of surichwi-injeulmi by adding surichwi contents. Korean J Soc Food Sci 17: 1-6.

7. Prinyawiwatkul W, Beuchat LR, Mcwatters KH. 1993. Functional property changes in partially defatted peanut flour caused by fungal fermentation and heat treatment. J Food Sci 58: 1318-1323.
8. Birch LL, Marin DW. 1982. I don't like it: I never tried it: Effects of exposure on two-year-old children's food preferences. Appetite 3: 353-361.

9. Moskowitz HR. 1994. Product optimization: approaches and applications. In Measurement of Food Preferences. MacFie HJH, Thomson DMH, eds. Blackie Academic \& Professional, London, UK. p 97-136.

10. Cornell JA. 1990. Experiment with Mixtures: Designs, Models, and the Analysis of Mixture Data. John Wiley \& Sons, New York, USA. p 352-435.

11. Borne MC. 1978. Textual profile analysis. Food Technol 32: $60-65$.

12. Szczesniak AS. 1975. General foods texture profile revisited ten years perspective. J Texture Stud 6: 5-12.

13. AOAC. 1990a. Official methods of analysis. 15th ed. Association of Official Analytical Chemists, Washington, DC, USA. p 334, 777-784.

14. Yamasita TR. 1968. Determination of $\alpha$-starch. Cookery Science 1: 24-26.

15. AOAC. 1990b. Protein efficiency ratio. In Official Methods of Analysis. 15th ed. Association of Official Analytical Chemists, Washington, DC, USA. p 1095.

16. Turner EW, Paynter WD, Montie EJ, Bessert MW, Struck GM, Olson FC. 1954. Use of the 2-thiobarbituric acid reagent to measure rancidity in frozen pork. Food Technol 8: $326-330$.

17. Chung CH, Toyomizu M. 1976. Studies on the browning of dehydrated foods as a function of water activity: I. Effect of Aw on browning in amino acid-lipid systems. Bull Jpn Soc Sci Fish 42: 697-702.

18. Minitab User's Guide. 2000. Data Analysis and Quality Tools. Minitab Inc., FL, USA. p 157-161.

19. Scheffe H. 1958. Experimens with mixtures. J Royal Stat Soc B20: 344-351.

20. Cardello AV. 1994. Consumer expectations and their role 
in food acceptance. In Measurement of Food Preferences. MacFie HJH, Thomson DMH, eds. Blackie Academic \& Prefessional, London, UK. p 253-297.

21. Sidel JL, Stone H. 1983. An introduction to optimization research. Food Technol 37: 36-43.

22. Fishken D. 1983. Consumer-oriented product optimization. Food Technol 37: 49-54.

23. MacDougall DB. 1983. Instrumental assessment of the appearance of foods. In Sensory Quality in Foods and Beverages: Definition, Measurement and Control. Williams AA, Atkin RK, eds. Verlag Chemie International Inc., Deerfield Beach, FL, USA. p 121-139.

24. Prinyawiwatkul W, Mcwatters KH, Beuchat LR, Phillips
RD. 1997. Optimizing acceptability of chicken nuggets containing fermented cowpea and peanut flours. $J$ Food Sci 62: 889-893.

25. Shin KS, Woo KJ. 1999. Changes in adding soybean on quality and surface structure of Korean rice cake (Jeungpyun). Korean J Soc Food Sci 15: 249-257.

26. Na HN, Yoon S, Kim JS, Kim BY. 1998. The activity and characteristics of $\alpha$-amylase present in soy milk and Jeung-pyun batters. Korean J Soc Food Sci 14: 261-265.

27. Ryu HS, Hwang EY, Lee JH, Cho HK. 1998. A new regression equation of $\mathrm{pH}$ drop procedure for measuring protein digestibility. J Food Sci Nutr 3: 180-185.

(Received October 6, 2010; Accepted December 6, 2010) 